\title{
The Relationship between Psychological Safety and Employee Voice: The Mediation Role of Affective Commitment and Intrinsic Motivation
}

Özlem YAŞAR UĞURLU

Gaziantep University

Department of Business Administration

Gaziantep, Turkey

yasar@gantep.edu.tr

\author{
Sibel AYAS \\ Gaziantep University \\ Department of Business Administration \\ Gaziantep, Turkey \\ sibelayas@gantep.edu.tr
}

\begin{abstract}
In this quantitative research, we enhance understanding of psychological safety on employee voice behavior by examining mediating role of affective commitment and intrinsic motivation. We examined these relationships among 151 research assistants working full-time for universities. The results suggest that psychological safety is significantly associated with affective commitment whereas it does not significantly influence intrinsic motivation. Furthermore, employee voice behavior is affected by intrinsic motivation but not by affective commitment. Lastly, while affective commitment plays an important role as mediator in the relationship between psychological safety and employee voice although intrinsic motivation does not have a mediating effect. We discuss the implications of these findings for both theory and practice.
\end{abstract}

Keywords: Psychological Safety, Prosocial Voice, Affective Commitment, Intrinsic Motivation, Academic Staff.

\section{Introduction}

In recent years, there has been a rapidly growing body of conceptual and empirical research focused on better understanding both individual, and situational factors that increase employee voice behavior. Employees may generate ideas, opinions and solutions in order to improve their work outcomes and therefore exhibit voice behavior (Dyne et al., 2013). However, employees might feel unsafe to express their ideas. Since, voicing comments which express a personal opinion for change in an organization is a risky behavior. It may cause to upset their leaders who establish a certain structure, processes, thoughts and routines in an organization (Gao et al., 2011). Despite the fact that employees do not work within an environment where they cannot speak up well (Milliken, Morrison, and Hewlin, 2003; Ryan and Oestrich, 1998), voice is still seen as a significant source of organizational learning and change (Sax and Torp, 2015). Research evidence suggests that employee voice makes an important contribution to organizational effectiveness, and high-quality decision making (Allen et al., 2015, p. 1274). Thus, it is important to better understand the mechanism which 
provides the behavior of voice within organizations. In this study, we seek to contribute to such understanding.

In the literature, studies have generally addressed three different approaches to influence employees' decisions to voluntarily provide comments or suggestions intended to promote organizational improvement. First group of researchers have focused on individual differences in personality and demographic characteristics as correlates of voice (Crant, 2003; LePine and Van Dyne, 2001) whereas second group investigates employee attitudes as the primary determinant of upward voice (Rusbult, Farrell, Rogers, and Mainous, 1988; Withey and Cooper, 1989). Thirdly, others have conducted their research on organizational context that may influence employees' tendency to speak up more (Dutton, Ashford, O'Neill, Hayes, and Wierba, 1997; Edmondson, 2003; Milliken et al., 2003). However, this study mainly focused on the role of affective commitment and intrinsic motivation in the relationship between psychological safety and employee voice.

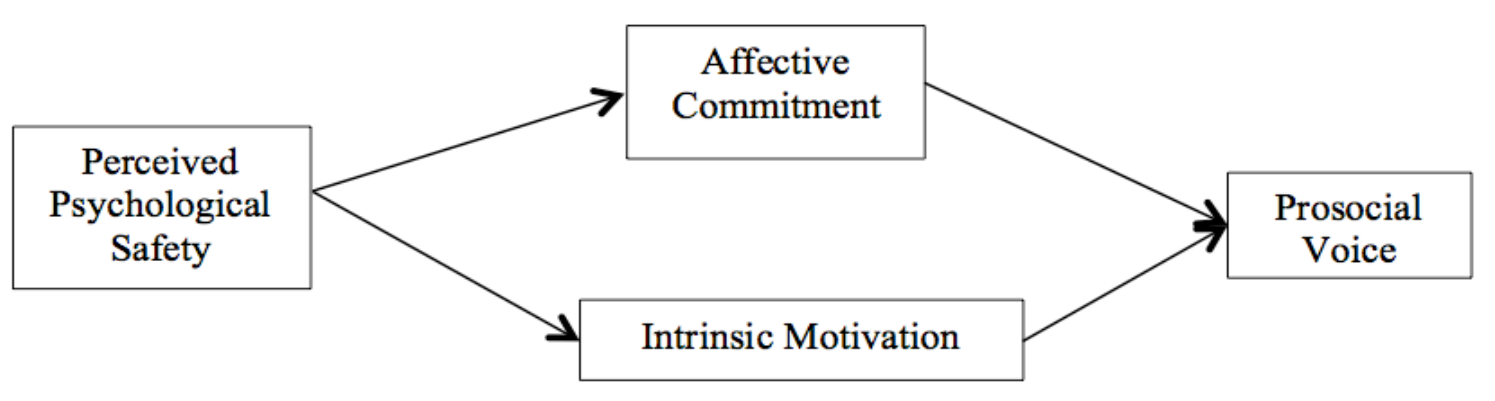

Figure 1. The conceptual model of the research

Therefore, the aim of this study was to address specifically employee attitudes as an influence on employees' voice behavior. It has been assumed that psychological safety may influence the level of voice behavior by the mediation of affective management and intrinsic management. Namely, psychological safety may promote affective commitment and intrinsic motivation and that this state will encourage individuals to voluntarily share their ideas and become involved in voice behavior.

\section{Conceptual Framework}

The term voice has been described "as representation of the intentional expression of work-related ideas, information, and opinions" (Dyne et al., 2013, p.1370). It is based on Hirschman's (1970) model of exit, voice and loyalty where voice means "any attempt at all to change, rather than to escape from, an objectionable state of affairs" (Gao et al., 2011, p. 788). Due to the fact that employee voice is a broad and complex concept, many different conceptions seem similar to it such as organizational dissent (Graham, 1986), voice (Brockner et al., 1998; Detert and Burris, 2007; Van Dyne and LePine, 1998), whistle blowing (Near and Miceli, 1985), issue selling (Ashford, Rothbard, Piderit, and Dutton, 1998), taking charge (Morrison and Phelps, 1999), and speaking up (Premeaux and Bedeian, 2003).

Previous studies have found many different concepts related to voice in both management and organizational behavior literature. For instance, research has shown that transformational leadership is one of the key elements in order to increase voice behavior (Detert and Burris, 2007). Evidence has found that perceived organizational 
support is significantly and positively associated with voice (Ashford et al.,1998) Dutton et al., $(1997,2002)$ has discovered that organizational culture might both encourage and discourage voice. The main reason behind the fact that voice behavior is so related many work attitudes might be that when employees are able to freely express their thoughts and given time to share their opinion, they may engage with voice behavior more frequently (Allen et al., 2015).

The dimensions of voice behavior are based on three concepts: prosocial voice, defensive voice, and acquiescent voice (Dyne et al., 2013). First of all, prosocial voice presents work-related ideas and opinions based on cooperative motives such as altruism. Hence, it means that prosocial voice is deliberate and proactive. The main focus here is to help others and promote organizational welfare (Dyne et al., 2013). Secondly, Dyne et al., (2013) defines defensive voice as self-protective and expressing work-related ideas based on fear with the goal of protecting the self. The main difference between defensive voice and prosocial voice is about motive which one is based on other self and another is based on self, respectively. Thirdly, acquiescent voice is especially concerning the verbal expression of work-related opinions - based on feelings of resignation (Dyne et al., 2013). In this research, we conceptualize employee voice as trustful and empowering environment and making constructive suggestions for doing things better. As prosocial voice has been accepted as challenging-promotive voice behavior (Van Dyne and LePine, 1998; Gao et al., 2011), we use the prosocial voice behavior.

The value of employee contribution is of great importance. Especially the notion of psychological safety has received a noticeable attention in the literature (Edmondson, 1999; Baer and Frese, 2003; Walumbwa and Schaubroeck, 2009). Psychological safety was defined by Brown and Leigh (1996) as an employee's 'sense of being able to show and employ one's self without fear of negative consequences to self-image, status or career' (p. 708). In addition, Edmondson (1999) explain psychological safety in work teams as a shared belief that a team feels safe while taking interpersonal risks. In the study of Baer and Frese (2003), a climate for psychological safety illustrated as an organization climate where employees feel safe to raise voice without fear and hesitation. In this research, we use the concept of psychological safety in individual level. In psychologically safe work environments, employees are encouraged to take personal risks because they believe that they are not punished for making any mistakes. Therefore, according to Milliken et al., (2003), it is so crucial to have a safe work environment to speak up and engage in voice behavior. As a result, this study is to examine the mechanism and relationship between psychological safety and employee voice.

\section{Psychological Safety - Affective Commitment - Prosocial Voice}

A psychologically safe work place may be seen as an environment where employees have interpersonal trust and a relationship based on mutual respect. It provides employees with shared beliefs that it is safe to take interpersonal risks (Hernandez et al., 2015). The psychological safety is generally emerged within an organization where top management takes an action for it (Rao-Nickholson et. al., 2015). Researchers have assumed that a non-threatening and supportive management plays a key role in identifying the presence of psychological safety (Hirak et al., 2012). It is because in an environment where 'proposing a new idea will lead to an attack, to 
him or her being censored, ridiculed or penalized...' (West, 1990, p. 312), it may enable employees to come up with new ideas and information and as a result engage in voice behavior.

The relationship between psychological safety and voice behavior may be mediated by commitment. Meyer and Allen in 1991 have identified three different types of commitment: affective, continuance, and normative commitment. They define affective commitment as employee's emotional attachment to, identification with, and involvement in the organization. Employees with a strong affective commitment to their organization feel that they are most likely to continue employment. It is just because they want to do so. Continuance commitment is concerning the costs when employees leave the organization. Thirdly, normative commitment refers to a feeling of obligation to continue working because of the fact that they ought to remain with the organization (Meyer and Allen, 1991, p. 67). Affective commitment appears most frequently and also will be used as mediator in the study. Meyer and his friends in 2002 conducted a meta-analysis and demonstrated that affective commitment has been more strongly and positively associated with job performance and organizational citizenship behavior.

In this research, it has been assumed that when employees psychologically feel safe, they will engage more in attitude of affective commitment. It is because a psychologically safe environment provides employees with high quality interpersonal relationships and feeling of attachment to the organization which in return may foster affective commitment. One of the more recent studies (Rathert et al., 2009) have found that psychological safety is significantly and positively related to affective commitment. Therefore we hypothesized:

Hypothesis 1: Psychological safety is positively associated with affective commitment.

As affective commitment refers to "a party's desire to continue a relationship because of the enjoyment of the relationship for its own sake" (Bloemer and Odekerken-Schröder, 2003:34), it could have an impact on employee voice. Since speaking up at work may need emotional attachment to the organization. Due to the fact that affective commitment provides employees with emotional attachment to, identification with, and involvement in the organization (Meyer and Allen, 1991), they may speak up without any hesitations. There are a number of studies on investigating the relationship between affective commitment and voice behavior (Fuller et al.,, 2006b; Withey and Cooper, 1989). Fuller et al., (2006a, p. 825) has argued that "individuals who exhibit voice behavior typically support organizational goals and devote effort to developing and expressing ways to overcome impediments to the achievement of those goals" (Allen and Meyer, 1990). Drawing from the theory by Hirschman (1970) who suggested that individuals with "that special attachment to an organization known as loyalty" (p. 77) are presumably to show voice behavior. Therefore we hypothesized:

Hypothesis 2: Affective commitment is positively associated with prosocial voice.

Employees feeling safe (psychological safety) in an organization are most likely to feel as belonging to the organization (affective commitment). As affective commitment has been accepted as a major factor of increased job performance (Meyer et al., 2002), which in turn can lead to increased voice behavior. In other words, if 
employees feel psychologically safe with their work conditions and the way they are treated by management, they are more likely to have higher levels of affective commitment to the organization. People high in affective commitment enjoy the affiliation in the organization and share its values and goals (Allen and Meyer, 1990). A few studies have illustrated that those high in affective commitment are more likely to engage in organizationally attitudes and behaviors such as extra effort as well as proactive and innovative behaviors similar to employee voice (Strauss et al., 2009). Specifically, there is only one study by Rathert et al., (2009) which investigate the positive relationship between affective commitment and employee voice. In this context, employees experiencing psychological safety at work might feel free to be themselves and take decisions freely (Rao-Nickholson et al., 2015) through affective commitment. Specifically, when employees' psychological safety is high, they will be more confident about speaking up at work without fear or hesitation so that their affective commitment to the organization may increase, which in turn allows the individual to sustain his behavior, such as voice up and self-expression (Zhang et al., 2010). Detert and Burris (2007) found that subordinates' sense of psychosocial safety has a positive impact on their improvement-oriented speaking behavior. Thus far, it has been argued that psychological safety raises employees' affective commitment, which, in turn, contributes to employee voice behavior. The present study tests this theorized mediating role of affective commitment. Building from all these arguments, the study proposes the following hypothesis:

Hypothesis 3: Affective commitment mediates the relationship between psychological safety and prosocial voice.

\section{Psychological Safety - Intrinsic Motivation - Prosocial Voice}

Psychological safety is accepted as a key instrument for rising engagement with work (Kahn, 1990), which has been supported by several studies (May et al., 2004). Similarly, psychological safety encourages employees in experiencing self-expressive behavior (Kahn, 1990). Investigation on psychological safety has attracted attention greater than before because it facilitates an interpersonal work context (Hirak et al., 2012). For instance, it may have influence on intrinsic motivation as a personal aspect.

In the present study, it has been suggested that psychological safety leads to intrinsic motivation. Looking at the literature, intrinsic motivation means motivational issue of which employees enjoy doing a task for its own sake, instead of the external outcomes or rewards such as money (Deci and Ryan, 1985). Basically, intrinsic motivation refers to what extent an employee is excited about a work activity (Utman, 1997). This study expects that employees working with high level of psychological safety would be intrinsically motivated. As a consequence, psychological safety is likely to promote the willingness of employees to give more attention and do better in their tasks.

In the work context, top management should generate an atmosphere where employees feel that their opinion is appreciated and where open-minded discussions are valued (Ekaterini, 2010). To create such a culture, organizations need to encourage employees to get involved in decision making by coming up with their ideas and taking them into consideration. Furthermore, organizations should support employees for expressing themselves, challenging the status quo and asking questions without fear of unexpected consequences (Sax ve Torp, 2015). For psychologically safe individuals, 
they feel secure raising problems and producing recommendations for progress (Walumbwa ve Schaubroeck, 2009). As a result we hypothesized:

Hypothesis 4: Psychological safety is positively associated with intrinsic motivation.

This study also assumes that intrinsic motivation is associated with employees' voice behavior. As voice behavior has been defined as "discretionary communication of ideas, suggestions, concerns, or opinions about work-related issues with the intent to improve organizational or unit functioning" (Ekrot et al., 2015, p.1), it could be reasonable to assume that intrinsic motivation could be one of the important determinants influencing voice behavior. Although there are not much research in order to investigate the relationship between intrinsic motivation and voice, Amabile (1988) notes that intrinsic motivation could be resulted in enthusiasm for the activity. When an employee is intrinsically attracted to a task, he/she probably exhibits more voice behavior and would be deeply taking part in the activity. This activity might be occurred as a behavior of voice. The reason why some people voice more than others might be to what extent they feel intrinsically motivated. Thus, leading to H5:

Hypothesis 5: Intrinsic motivation is positively associated with prosocial voice.

According to Deci's (1975) Cognitive Evaluation Theory, there are two key factors of intrinsic motivation: feelings of personal control and feelings of competence. When people are more intrinsically motivated, they may feel personal control and competence much stronger (Fischer, 1978:273). For this to occur, intrinsic motivation requests a psychologically safe environment to bring out. A key assumption here is that voice is usually helpful with the central motive to support the organization. As a result, individual factors have an impact on voice behavior (Van Dyne et al., 2003; Morrison, 2011).

Additionally, top management need to stimulate an environment which is more tolerant of speaking up about mistakes and circumstances (Hirak et al., 2012). As this study also suggests that employees who feel psychologically safe, it is more likely to lead to higher levels of voice behavior with mediating role of intrinsic motivation. To put it another way, voice behavior could be stimulated when people working in a psychologically safe culture have a feeling of intrinsic motivation by working together. One of the reasons why intrinsic motivation could be a source of employee voice behavior is that because employees might perceive their work environment as noncontrolling and free to speak up about the issues in organizations. Thus far, it has been argued that psychological safety enable employees to be more intrinsically motivated, which, in turn, contributes to prosocial voice behavior. The present study tests this theorized mediating role of intrinsic motivation.

Hypothesis 6: Intrinsic motivation mediates the relationship between psychological safety and prosocial voice.

\section{Methodology}

The present study has been conducted in Turkish universities. Significantly, with the exception of the work of Barnes et al., (2013), there is little research on employee voice behavior in the universities. We specifically conducted our research in universities. It is because TUBITAK (The Scientific and Technological Research Council of Turkey) has been publishing Entrepreneur and Innovator University Index since 2012 in order to develop political instruments triggering innovativeness and 
entrepreneurship in universities. The Index has contributed to entrepreneurship and competitiveness based on innovation. Universities have been ranged over 20 indicators such as research competency, innovative culture, cooperation and interaction and economical contribution. Therefore, voice behavior as a key component for the changing of creative ideas into successfully implemented innovations (Rank et al., 2004) become crucial for universities.

Research assistants in universities have been chosen as sample of this study. The reason why specifically research assistants have been selected is because previous studies have underlined that lower-level employee behavior is of great importance for risk recognition and evaluation in a changing world (Burgelman and Grove, 2006; Meeus and Edquist, 2006). Employees from low level of organization may much easily broaden the scope of input and raise the speed (Dutton and Ashford, 1993).

\section{Respondents and Data Collection}

Participants in the present study were research assistants in both state and private universities in Gaziantep, Turkey. The participants were employed across 41 different departments at the universities. Although 220 questionnaires were distributed face-toface, only 151 (\%68 overall response rate) surveys were returned as completed. The respondents' average age was between $25-28$ years (s.d. 0,84 ), and their average tenure within the organization was 3.65 years (s.d. 2.78).

This study was designed as a cross-sectional survey using an anonymous selfreport questionnaire. The measurement instrument was created through an extensive review of the literature. Most measures were adapted and modified to make them more suitable for this research setting.

\section{Measures}

Employee voice was measured by five items of prosocial employee voice adapted from Dyne et al., (2003). All items were rated using a 5-point scale ranging from 1 "strongly disagree" to 5 "strongly agree". Sample item was "I express solutions to problems with the cooperative motive of benefiting the organization". Cronbach's alpha for this measure was 0.89 .

The measure of psychological safety contained seven items developed by Edmondson (1999). A sample item is 'When someone in our company makes a mistake, it is often held against them' (reversed coded). All items were rated using a 5-point scale ranging from 1 "strongly disagree" to 5 "strongly agree". Cronbach's alpha for this measure was 0.76 .

The scale of affective commitment was borrowed from Meyer and Allen (1990) and contained six items. All items were rated using a 5-point scale ranging from 1 "strongly disagree" to 5 "strongly agree". Sample item was "I would be very happy to spend the rest of my career with this organization". Cronbach's alpha for this measure was 0.92 .

The 5-item intrinsic motivation scale developed by Tierney et al., (1999) was used. All items were rated using a 5-point scale ranging from 1 "strongly disagree" to 5 "strongly agree". Sample items were "I enjoy finding solutions to complex problems". Cronbach's alpha for this measure was 0.86 .

In our analysis, we controlled several demographic characteristics of the respondents, including gender, age and organizational tenure. It has been used various control variables to be reasons for alternative explanations of voice behavior. First of 
all, evidence (LePine and Van Dyne, 1998; Detert and Burris, 2007) has shown that various demographic variables could influence voice. For instance, organizational tenure may have impact on speaking up because of the fact that former employees might be more comfortable than newcomers (Stamper and Van Dyne, 2001). Secondly gender has been analyzed as a control variable (Detert and Burris, 2007). Finally, we have controlled age whether it affects employee voice behavior (Tangirala and Ramanujam, 2008).

\section{Analytical Procedure}

To test the model in Figure 1, we performed structural equation modeling (SEM) (Bollen, 1989) using AMOS 5 (Arbuckle and Wothke, 2003). In order to assess the fit of the research model, we used several goodness-of-fit indices as suggested in structural equation modeling literature (Joreskog and Sorbom, 1993; Kline, 1998) such as Chi-Square statistics divided by the degree of freedom ( $\left.\chi_{2} / \mathrm{df}\right)$; comparative fit index (CFI), Incremental fit index (IFI), Tucker-Lewis coefficient (TLI), and root mean square error of approximation (RMSEA). As suggested in the SEM literature (Joreskog and Sorbom, 1993; Kline, 1998), we used the following criteria for goodness-of-fit indices to assess the model-fit: $\chi 2 / \mathrm{df}$ ratio is recommended to be less than 3 ; the values of IFI, TLI and CFI recommended to be greater than 0.90; RMSEA is recommended to be up to 0.05 , and acceptable up to 0.08 .

This study used Anderson and Gerbing's (1988) recommendation which is a twostep approach. First, authors have used confirmatory factor analysis investigating whether the four work outcomes in fact represented four different constructs whereas the hypotheses were tested using structural equation models as a second step. First of all, the measurement model has been built for conducting a confirmatory factor analysis of the variables including psychological safety, intrinsic motivation, affective commitment, and employee voice.

\section{Results}

The means, standard deviations, and correlations for the research variables are presented in Table 1. The bivariate correlations indicate that psychological safety is significantly associated with prosocial voice $(\mathrm{r}=.16, \mathrm{p}<.005)$. We have also found that prosocial voice is related to both affective commitment and intrinsic motivation $(r=41$, $\mathrm{p}<.001 ; \mathrm{r}=42, \mathrm{p}<.001)$.

Table 1. Means, standard deviations and correlations

\begin{tabular}{llllllllll}
\hline & Mean & s.d. & 1 & 2 & 3 & 4 & 5 & 6 & 7 \\
\hline 1.Gender & 1,50 & 0,50 & - & & & & & & \\
2.Age & 3,41 & 0,84 & -.12 & - & & & & & \\
3.Tenure & 3,65 & 2,78 & -.02 & $.67^{* *}$ & - & & & & \\
4.Psychological Safety & 3,38 & 0,86 & -.04 & -.17 & -.23 & - & & & \\
5.Affective commitment & 3,42 & 1,00 & .03 & -.00 & -.03 & $.49^{* *}$ & - & & \\
6.Intrinsic Motivation & 4,13 & 0,62 & -.13 & .11 & .15 & .08 & $.27^{* *}$ & - & \\
7.Prosocial Voice & 3,58 & 0,86 & $-.17^{*}$ & .09 & $.16^{*}$ & $.24^{* *}$ & $.41^{* *}$ & $.42^{* *}$ & - \\
\hline
\end{tabular}




\section{Preliminary Analyses}

After six items with factor loading less than .5 were deleted (item 1,3,4,5 for psychological safety; item 3 for affective commitment and item 3 for prosocial voice), we had a reasonable fit between the model and the data according to the study of $\mathrm{Hu}$ and Bentler (1999) [ $\chi 2(112)=203,886, p=.000 ;$ RMSEA $=.07$; CFI $=.94$; IFI= .94]. All items had significant loadings (all above .54, $<<.001$ ) on the intended factors.

The measurement model supports that there is discriminant validity among the measures which were distinct from each other (Lance et al., 1988). We also examined three alternative measurement models: (1) a one-factor model, (2) a two-factor model where items measuring psychological safety and intrinsic motivation were loaded onto one factor and the items measuring affective commitment, and employee voice loaded onto another factor; and (3) a three-factor model where items measuring psychological safety and intrinsic motivation were loaded onto one factor, the items measuring affective commitment were loaded onto another factor and the items measuring employee voice loaded onto another factor as well.

Table 2. Model Fits for Measurement Model.

\begin{tabular}{lllllll}
\hline & df & $\chi^{2}$ & CFI & TLI & IFI & RMSEA \\
\hline One factor model & 118 & 882,681 & .54 & .47 & .55 & .20 \\
Two factor model & 117 & 530,957 & .75 & .71 & .75 & .15 \\
Three factor model & 115 & 302,356 & .88 & .86 & .89 & .10 \\
$\begin{array}{l}\text { Baseline (four factor) } \\
\text { model }\end{array}$ & 112 & 203,886 & .94 & .93 & .94 & .07 \\
\hline
\end{tabular}

There were significant differences between the three nested models (one- ,two-, three factor models) and the baseline model (four-factor model). Chi-square difference between the baseline model and the one factor model (678.795, df differences $=6$, $\mathrm{p}<.01$ ), as well against the two-factor model (327.071, df differences $=5, \mathrm{p}<.01$ ), as well against the three-factor model $(98.47$, df differences $=3, \mathrm{p}<.01)$ further supported the preference of the four-factor model. Thus, these findings indicate that the hypothesized four-factor model had better fit with the data and therefore we accepted this measurement model.

\section{Test of the Model}

We used maximum likelihood SEM to test our model's hypotheses. As mentioned earlier, we evaluated model fit using various fit indices and the significance of the completely standardized path estimates (Bollen, 1989). The structural model produced a good fit of the data $\left[\chi^{2}(113)=215,248 ; \mathrm{p}<.001\right.$; RMSEA $=.07$; CFI $=.93$; $\mathrm{IFI}=.94 ; \mathrm{TLI}=.92]$. The multiple squared correlation coefficients $\left(\mathrm{R}^{2} \mathrm{~s}\right)$ for affective commitment, intrinsic motivation and employee voice were $0.34,0.02$ and 0.30 , respectively.

The findings support Hypothesis 1 which predicted that there would be a positive relationship between psychological safety and affective commitment $(0.58, \mathrm{p}<.001)$. However, the results have shown no evidence for Hypothesis 2 which posited that affective commitment would be positively and significantly associated with employee voice $(0.16$, p: n.s.). Furthermore, the results failed to confirm Hypothesis 4 which predicted that there would be a positive relationship between psychological safety and 
intrinsic motivation $(0.12, p=n . s$.$) . However, the results provide support for Hypothesis$ 5 which posited that intrinsic motivation would be positively and significantly associated with prosocial voice $(0.43, \mathrm{p}<.001)$.

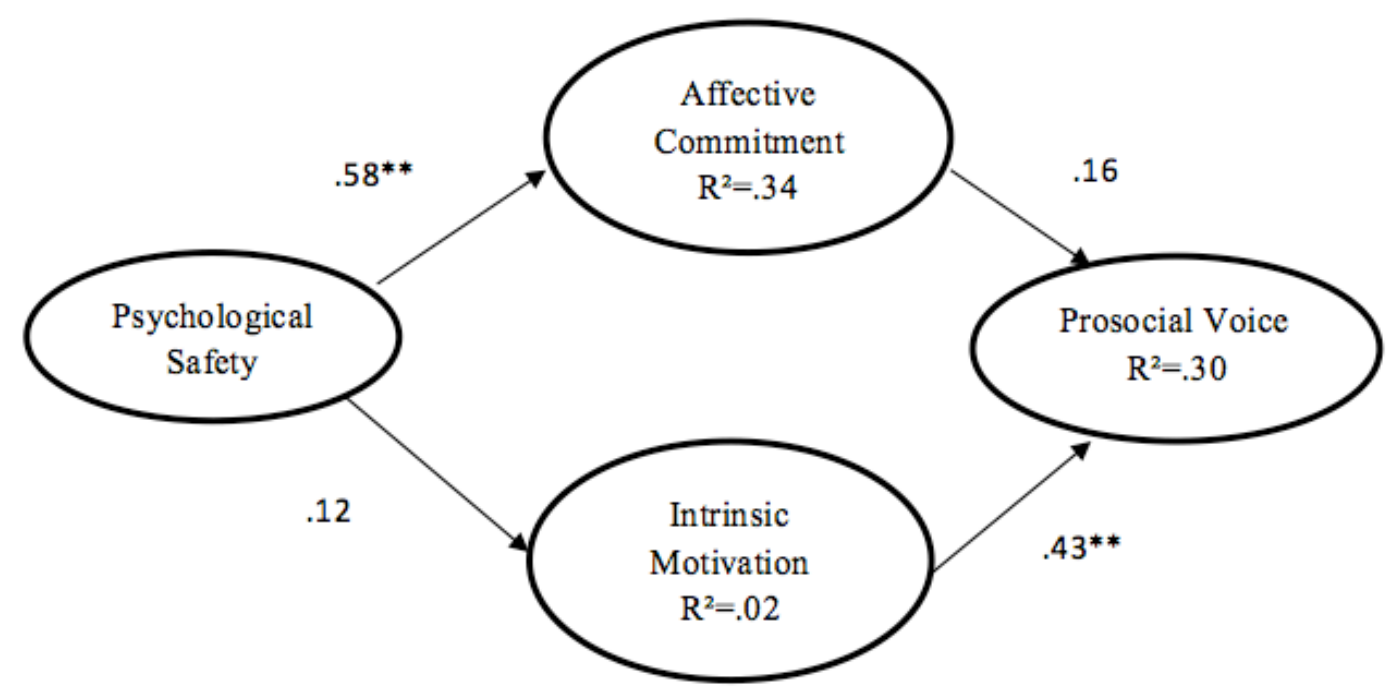

Figure 2. The Reseacrh Model

Note: Standardized parameter estimates. $\mathrm{N}=151{ }^{* *} \mathrm{p}<.001$; this is a simplified version of the actual model. It does not show indicators, error terms, covariance or exogenous factor variances

Following the procedure outlined by Baron and Kenny (1986) we used SEM to test the mediating effect of affective commitment and intrinsic motivation in the relationship between psychological safety and prosocial work. First of all, when affective commitment (the mediator) was specified, we found that the relationship between psychological safety and prosocial voice was insignificant, $(0.31, p<.001$. vs. $0.12, \mathrm{p}=$ n.s.). The relationships between psychological safety and affective commitment remained significant $(0.58, \mathrm{p}<.001)$. These findings indicate full mediation; there is both a direct and an indirect (through affective commitment) significant relationship between psychological safety and prosocial voice, which thus support Hypothesis 3 that posited a full mediating relationship between psychological safety, affective commitment and prosocial voice. The results of this fully mediated model are shown in Figure 2.

For testing the mediating effect of intrinsic motivation in the relationship between psychological safety and prosocial voice, Baron and Kenny's first step which is the relationship between independent variable (psychological safety) and mediator (intrinsic motivation) was not found significant $(0.12, \mathrm{p}=$ n.s. $)$. Therefore, hypothesis 6 was not supported.

\section{Discussion and Conclusion}

The main goal of this study was to examine the role of psychological safety in prosocial voice, and the role of affective commitment and intrinsic motivation as a possible intervening mechanism that mediates the relationship between psychological 
safety and prosocial voice. One of the findings of this study, as predicted, shows that psychological safety affects affective commitment (H1). This evidence is in line with the research of Rathert et al., (2009). Increased psychological safety was associated with increased levels of employee commitment and engagement. In psychologically safe work environments as defined by Edmondson (1996, 1999), employees feel safe to take interpersonal risks; they believe they will not be excessively or unfairly punished for making honest mistakes, asking for help, or seeking additional feedback and information. So they can easily commit to the organization.

Although the literature has found conflicting results (Ekrot et al., 2015; Fuller et al.,, 2006; Goodwin and Verhage, 1989), the hypothesis in the research regarding the relationship between affective commitment and employee voice was not supported (H2). In other words, contrary to expectations, commitment did not play a significant role in explaining the likelihood of prosocial voice in our study. This finding is also in line with the results of Bove and Robertson (2005). This insignificant relationship could stem from the nature of voice behavior itself. It means that people who more speak up may not be motivated of being committed to the organizations. There could be other determinants of voice behavior such as intrinsic motivation.

Furthermore, it was also found that affective commitment mediates the relationship between psychological safety and prosocial voice $(\mathrm{H} 3)$. This finding is in line with the literature (Ekrot et al., 2015). As Hirschman (1970) proposed in his voice theory, organization members' loyalty, which is highly similar to affective commitment, activates voice and reduces the likelihood of other outcomes such as exit and silence. So, affectively committed workers identify themselves with the values and goals of the organization (Wiener, 1982) and accordingly seem to use a strong collaboration to address and discuss suggestions for improvement or ideas.

The hypothesis regarding the relationship between psychological safety and intrinsic motivation was not supported (H4). The possible explanation of this result might be that when employees feel psychologically safe, it does not mean that they have to feel intrinsically motivated. There could be other factors in which psychological safety may have an impact on such as affective commitment.

Another key finding in this study is that contrary to affective commitment, intrinsic motivation is significantly associated with prosocial voice (H5). Although there are not much research in order to investigate the relationship between intrinsic motivation and voice, Amabile (1988) notes that intrinsic motivation could be resulted in enthusiasm for the activity. Accepting prosocial voice behavior as an activity, when an employee is intrinsically attracted to a task, he/she probably exhibits more voice behavior and would be deeply taking part in the activity. This activity might be occurred as a behavior of voice.

Lastly, the present study examining the mediating effect of intrinsic motivation on the relationship between psychological safety and employee voice behavior was not supported (H6). In the literature, there is not much research on whether intrinsic motivation has a mediating effect in this relationship or not. Although intrinsic motivation was assumed to be an important indicator in organizational behavior literature, this research found that affective commitment has been much more important than intrinsic motivation in terms of delivering the effect of psychological safety on voice. 
This study makes both theoretical and practical contributions to the employee voice and psychological safety literature in several ways. First of all, this research could be accepted primarily attempt to looking at the mediating role of intrinsic motivation in the association between psychological safety and employee voice. In addition to that, as employee voice literature is growing, this study helps this field expand by determining the antecedents of employee voice behavior.

From practical view, as this study has been conducted on research assistants, it guides top management of universities as how to maintain employee voice behavior among faculty members. As voice is a key antecedent for innovation and entrepreneurship, university staffs are more likely to produce enterprising and innovative output when they are more engaged in speaking up at work.

\section{Limitations and Further Studies}

Even though questionnaires were used as a field study which enables the author to generalize the results and obtains greater external validity comparing to laboratory studies (Shalley and Zhou, 2009), it causes a limitation due to the fact that all data was collected within a short time and at the same time, thus it cannot be assumed that one factor brought about another factor. Besides, because the study was cross-sectional in design, findings cannot give any information about causality. Also, the small number of sampling size can be thought as another limitation of this study.

The participants in this study were employed research assistants at the university. Future research could replicate these findings in manufacturing sectors. Future research might also examine other indicators of the work context, apart from psychological safety, affective commitment and intrinsic motivation. In addition, voice behavior may be analyzed as group level to test the differences between individuals and groups. Lastly, this study might be conducted in different countries whether cultural variations may be the case in this concept.

\section{References}

Allen, N. J., Meyer, J. P., (1990). "The measurement and antecedents of affective, continuance, and normative commitment to the organization", Journal of Occupational Psychology, Vol: 63, 1-18.

Allen, N. J., Meyer, J. P., (1993). "Organizational commitment: evidence of career stage effects?", Journal of Business Research, Vol: 26, 49-61.

Allen, J. A., Yoerger, M. A., Willenbrock, N. L., Jones, J., (2015),"Would you please stop that!?: The relationship between counterproductive meeting behaviors, employee voice, and trust ", Journal of Management Development, Vol. 34, No: $10,1272-1287$.

Amabile, T. M., (1988). "A model of creativity and innovation in organizations", Research in Organizational Behavior; Vol: 10, 123-167.

Anderson, J. C., Gerbing, D. W., (1988). "Structural equation modeling in practice: A review and recommended two-step approach" Psychological Bulletin, Vol: 103, No: 3, 411- 423.

Arbuckle, J. L., Wothke, W., (2003). Amos 5.0 User's Guide. Chicago, IL: SPSS. 
Ashford, S., Rothbard, N., Piderit, S., Dutton, J., (1998). "Out on a limb: The role of context and impression management in selling gender-equity issues", Administrative Science Quarterly, Vol: 43, 23-57.

Baer, M., Frese, M., (2003). "Innovation is not enough: Climates for initiative and psychological safety, process innovations, and firm performance", Journal of Organizational Behavior, Vol: 24, No: 1, 45-68.

Barnes, A., MacMillan, C., Markey, R., (2013). "Maintaining union voice in the Australian university sector: Union strategy and non-union forms of employee participation”, Journal of Industrial Relations, Vol: 55, No: 4, 565-582.

Bennett,T., (2010), "Employee voice initiatives in the public sector: views from the workplace", International Journal of Public Sector Management, Vol. 23, No: 5, $444-455$.

Bloemer J., Odekerken- Schröder, G., (2003). "Antecedents and consequences of affective commitment", Australasian Marketing Journal Vol:11, No:3, 33-43.

Bollen, K. A., (1989). "A new incremental fit index for general structural equation models", Sociological Methods and Research, Vol: 17, No: 3, 303-316.

Brockner, J., Heuer, L., Siegel, P. A., Wiesenfeld, B., Martin, C., Grover, S., Bjorgvinsson, S., (1998). "The moderating effect of self-esteem in reaction to voice: Converging evidence from five studies", Journal of Personality and Social Psychology, Vol: 75, No: 2, 394-407.

Brown, S. P., Leigh, T. W., (1996). "A new look at psychological climate and its relationship to job involvement, effort, and performance", Journal of Applied Psychology, Vol: 81, No: 4, 358-368.

Burgelman, R., Grove, A.S., (2006). Strategic Dynamics: Concepts and Cases, McGraw-Hill, Boston, MA.

Carmeli, A., (2007). "Social capital, psychological safety and learning behaviors from failure in organisations", Long Range Planning, Vol: 40, 30-44.

Deci, E. L., (1975). Intrinsic motivation, Plenum Press, New York.

Deci, E. L., Ryan, R. M., (1985). "The general causality orientations scale: Selfdetermination in personality", Journal of Research in Personality, Vol: 19, No: 2, 109-134.

Detert, J. R., Burris, E. R., (2007). "Leadership behavior and employee voice: Is the door really open?", Academy of Management Journal, Vol: 50, No: 4, 869-884.

Dutton, J.E., Ashford, S.J. (1993), "Selling issues to top management", The Academy of Management Review, Vol. 18 No. 3, 397-428.

Dutton, J. E., Ashford, S. J., O'Neill, R. M., Hayes, E., Wierba, E.E., (1997). "Reading the Wind: How Middle Managers Assess the Context for Selling Issues to Top Managers", Strategic Management Journal, Vol: 18, No: 5, 407-423.

Dutton, J.E., Ashford, S.J., Lawrence, K.A., Miner-Rubino, K., (2002). "Red light, green light: Making sense of the organizational context for issue selling". Organization Science, Vol: 13, 335-369. 
Edmondson, A., (1999). "Psychological safety and learning behavior in work teams", Administrative Science Quarterly, Vol: 44, No: 2, 350-383.

Edmondson, A. C., (2003). "Speaking up in the operating room: how team leaders promote learning in interdisciplinary action teams", Journal of Management Studies, Vol: 40, No: 6, 1419-1452.

Ekaterini, G., (2010), "The impact of leadership styles on four variables of executives workforce", International Journal of Business and Management, Vol. 5, No: 6, 316.

Ekrot, B., Johannes R., Gemünden, H. G., (2015). “Antecedents of project managers' voice behavior: The moderating effect of organization-based self-esteem and affective organizational commitment", International Journal of Project Management, http://dx.doi.org/10.1016/j.ijproman.2015.10.011.

Fisher, C. D., (1978). "The Effects of Personal Control, Competence, and Extrinsic Reward Systems on Intrinsic Motivation", Organizational Behavior and Human Performance, Vol: 21, 273-288.

Fuller, J.B., Hester, K., Barnett, T., Frey, L., Relyea, C., Beu, D., (2006a). "Perceived external prestige and internal respect: new insights into the organizational identification process" Human Relations, Vol: 59, 815-846.

Fuller, J.B., Marler, L.E., Hester, K., (2006b). "Promoting felt responsibility for constructive change and proactive behavior: exploring aspects of an elaborated model of work design" Journal of Organizational Behavior, 27, 10891120.

Gao, L., Janssen, O., Shi, K., (2011). "Leader trust and employee voice: The moderating role of empowering leader behaviors", The Leadership Quarterly, Vol: 22, 787798.

Graham, Jill W., (1986). "Principled organizational dissent: A theoretical essay", Research in Organizational Behavior, Vol: 8, 1-52.

Guchait, P., Paşamehmetoğlu, A., Dawson, M., (2014). "Perceived supervisor and coworker support for error management: Impact on perceived psychological safety and service recovery performance", International Journal of Hospitality Management, Vol: 41, 28-37.

Hernandez, W., Luthanen, A., Ramsel, D., Osatuke, K., (2015). "The mediating relationship of self-awareness on supervisor burnout and workgroup civility and psychological Safety: A multilevel path analysis", Burnout Research, Vol: 2, 3649.

Hirak, R., Peng, A.C., Carmeli, C., Schaubroeck, J.M., (2012). "Linking leader inclusiveness to work unit performance: The importance of psychological safety and learning from failures", The Leadership Quarterly, Vol: 23, 107-117.

Hirschman, A.O., (1970). Exit, Voice, and Loyalty, Harvard University Press, Cambridge.

Jöreskog, K. G., and Sörbom, D., (1993). LISREL 8: Structural equation modeling with the SIMPLIS command language", Scientific Software International. 
Kahn, W. A., (1990). "Psychological conditions of personal engagement and disengagement at work", Academy of management journal, Vol: 33, No: 4, 692724.

Kline, R. B., (1998). "Software review: Software programs for structural equation modeling: Amos, EQS, and LISREL", Journal of Psychoeducational Assessment, Vol: 16, No: 4, 343-364.

LePine, J.A., Van Dyne, L., (1998). "Predicting voice behavior in work groups", Journal of Applied Psychology, Vol: 83, 853-868.

May, D. R., Gilson, R. L., Harter, L. M., (2004). "The psychological conditions of meaningfulness, safety and availability and the engagement of the human spirit at work", Journal of Occupational and Organizational Psychology, Vol: 77, No: 1, $11-37$.

Meeus, M., Edquist, C., (2006), "Introduction to part I", in Hage, J. and Meeus, M. (Eds), Innovation, Science, and Institutional Change, Oxford University Press, New York, 1-37.

Meyer, J.P., Allen, N.J., (1991). "A three-component conceptualization of organizational commitment", Human Resource Management Review, Vol: 1, No: 1, 61-89.

Meyer, J.P., Stanley, D.J., Herscovitch, L., Topolnytsky, L., (2002). "Affective, continuance, and normative commitment to the organization: a metaanalysis of antecedents, correlates, and consequences", Journal of Vocational Behavior, Vol: $61,20-52$.

Milliken, F.J., Morrison, E.W., Hewlin, P.F., (2003), "An exploratory study of employee silence: issues that employees don't communicate upward and why", Journal of Management Studies, Vol: 40, No: 6, 1453-1476.

Morrison, E.W., (2011). "Employee voice behavior: integration and directions for future research". The Academy of Management Annals, Vol: 5, No: 1, 373- 412.

Morrison, E. W., Phelps, C. C., (1999). "Taking charge at work: Extra role efforts to initiate workplace change", Academy of management Journal, Vol: 42, No: 4, 403-419.

Near, J. P., Miceli, M. P., (1985). "Organizational dissidence: The case of whistleblowing”, Journal of Business Ethics, Vol: 4, No:1, 1-16.

Premeaux, S. F., Bedeian, A. G., (2003). "Breaking the silence: The moderating effects of self-monitoring in predicting speaking up in the workplace", Journal of Management Studies, Vol: 40, 1537-1562.

Rank, J., Pace, V. L., Frese, M., (2004). "Three avenues for future research on creativity, innovation, and initiative", Applied Psychology, Vol: 53, No: 4, 518528.

Rao-Nicholson, R., Khan, Z., Stokes, P., (2015). "Making great minds think alike: Emerging market multinational firms' leadership effects on targets' employee 
psychological safety after cross-border mergers and acquisitions", International Business Review, http://dx.doi.org/10.1016/j.ibusrev.2015.09.007

Rathert, C., Ishqaidef, G., May, D. R., (2009). "Improving work environments in health care: Test of theoretical framework", Health Care Management Review, Vol: 34, No: 4, 334-343.

Rusbult, C. E., Farrell, D., Rogers, G., Mainous, A. G., (1988). "Impact of exchange variables on exit, voice, loyalty, and neglect: An integrative model of responses to declining job satisfaction”. Academy of Management journal, Vol: 31, No: 3, 599-627.

Ryan, K. D., Oestreich, D. K., (1998). Driving fear out of the workplace (2nd ed.). San Francisco: Jossey-Bass.

Ryan, R. M., Deci, E. L., (2000). "Intrinsic and Extrinsic Motivations: Classic Definitions and New Directions", Contemporary Educational Psychology, Vol: $25,54-67$.

Sax, J., Torp, S. S., (2015). "Speak up! Enhancing risk performance with enterprise risk management, leadership style and employee voice", Management Decision, Vol: 53, No: 7, $1452-1468$.

Shalley, C.E., Zhou, J., (2009). Organisational creativity research: A historical overview. In J. Zhou, and C.E. Shalley, (Eds.), Handbook of Organizational Creativity, Hillsdale, NJ: Lawrence Erlbaum.

Stamper, C. L., Dyne, L. V., (2001). "Work status and organizational citizenship behavior: A field study of restaurant employees", Journal of Organizational Behavior, Vol: 22, No: 5, 517-536.

Strauss, K., Griffin, M.A., Rafferty, A.E., (2009). "Proactivity directed toward the team and organization: the role of leadership, commitment and role-breadth selfefficacy", British Journal of Management, Vol: 20, 279-291.

Tangirala, S., Ramanujam, R., (2008). "Employee silence on critical work issues: The cross level effects of procedural justice climate", Personnel Psychology, Vol: 61, No: 1, 37-68.

Tierney, P., Farmer, S. M., Graen, G. B., (1999). “An examination of leadership and employee creativity: The relevance of traits and relationships", Personnel Psychology, Vol: 52, No: 3, 591-620.

Utman, C. H., (1997). "Performance effects of motivational state: A meta-analysis", Personality and Social Psychology Review, Vol: 1, No: 2, 170-182.

VanDyne, L., Ang, S., Botero, I.C., (2003). "Conceptualizing employee silence and employee voice as multidimensional constructs", Journal of Management Studies, Vol: 40, No: 6, 1359-1392.

Walumbwa, F. O., Schaubroeck, J., (2009). "Leader personality traits and employee voice behavior: Mediating roles of ethical leadership and work group psychological safety", Journal of Applied Psychology, Vol: 94, 1275-1286.

West, M. A., (1990). The social psychology of innovation in groups. West, Michael A. (Ed); Farr, James L. (Ed), (1990). Innovation and creativity at work: 
Psychological and organizational strategies. , (pp. 309-333). Oxford, England: John Wiley and Sons.

Withey, M.J., Cooper, W.H., (1989). "Predicting exit, voice, loyalty, and neglect", Administrative Science Quarterly, Vol: 34, 521-539.

Zhang, Y., Fang, Y., Wei, K-K., Chen, H., (2010). "Exploring the role of psychological safety in promoting the intention to continue sharing knowledge in virtual communities", International Journal of Information Management, Vol: 30, 425436. 